\title{
SOCIAL DIMENSIONS TO THE PUBLIC TRANSPORT SYSTEM IN KYIV
}

\author{
Olena Dronova \\ Department of Economic and Social Geography, Taras Shevchenko National University of Kyiv \\ Instytutska St. 18, Apt. 59, 01021, Kyiv: Ukraine \\ olena.dronova@gmail.com
}

\begin{abstract}
This paper focuses on distinctive features of accessibility, passenger flow and sustainability as regards public transport in Kyiv, Ukraine. In investigating the impacts of a transport system on city-dwellers a key concept is accessibility. The analysis included here identifies clear patterns to the individual factors that influence commuting time. Since the city's system of public transport is underdeveloped, the main underlying factor is the presence of metro lines. An analysis of the metro passenger-traffic system confirms the persistent presence of territorial disparities in the city's transport network. Furthermore, levels of safety, environmental friendliness and comfort experienced gain reflection in a low level of consumer confidence in the city's transport system, as well as its limited sustainability. Priority measures by which the current situation might be improved are therefore discussed.
\end{abstract}

Keywords: public transport, accessibility, traffic flows, sustainability, Kyiv, Ukraine.

\section{Introduction}

In all countries, the sustainable and effective operations of systems of public transport represent key factors favouring harmonious socio-economic development. In a positive context they reflect high quality-of-life standards for citizens. In turn, differences in transport accessibility a population experiences reflects transport "injustice", whereby all aspects of life in an urban or rural society can be affected. Key issues relating to the impacts of public transport systems include the mobility, comfort and safety of residents, and the search for ways in which the entire transport service system might be improved. These issues require the attention of scholars and public agencies in many countries, including Ukraine.

In current geographical research on transport systems, it is qualitative aspects and social issues that merit special attention and are often considered of prime importance. Themes heading the list in this case include accessibility, connectivity, mobility and transport justice, as well as efforts to increase the value of transport as it relates to the overall spatial development and planning taking place in cities, countries and regions (Farrington, 2007; Hall, 2010; Kenyon, 2011; Stępniak, Rosik \& Komornicki, 2013; Mackett \& Thoreau, 2015).

The social meaning of the transport good and the justice principle guiding its distribution relate to overall development - as Martens $(2009,2012)$ has stressed, on the basis of Walzer's 
'Spheres of Justice' concept (1983). According to Martens, transport is of social meaning in the sphere of concepts also including freedom of choice and freedom of movement. This conceptual framework is thus of particular importance as transport issues are addressed. It reflects opportunities, and possible linkages with other places, for example, for those seeking access to increased opportunities and the freedom to experience areas beyond one's locality. From a distributive transport perspective, Martens supports other authors (Vigar, 1999; Ross, 2000; Garb \& Levine, 2002) in considering two distinct social aspects to the good that is transport, i.e. potential mobility and person accessibility, defined in general as accessibility (Martens, 2012). The argument runs that justice principles, as they relate to the distribution of the transport good, rarely play a role in traditional, market-related planning of transport. But consideration of this kind needs to be given, especially where government interventions in the development of transport are concerned.

Research on social exclusion extends to common transport problems faced by deprived groups in the population. Thus decisions as regards the non-feasibility of a doctor's appointment, job interview, meeting with family and friends and so all may all end up being made in line with the lack of an adequate means of transport (e.g. Hine \& Mitchell, 2001; Raje, 2003; Rose et al., 2009; Lucas, 2010). In this same context, Jaroš (2017) discusses process of social exclusion as they relate to transport issues, noting how transport accessibility may be both a factor underlying the appearance and deepening of social inequalities, and a source of empowerment integrating excluded individuals and helping them overcome social disadvantages.

In many ways transport and social exclusion research has moved on over the last 17 years tonow include more social issues. Numerous studies are measuring and modelling the many and varied aspects of transport-related social exclusion within different national and local contexts. What is more, transport and social exclusion research has spread to many countries largely in recognition of its utility in identifying the intersecting roles of transport, land-use planning and service-delivery decisions as efforts are made to reduce both poverty and social disadvantage (Lucas, 2011).

Studies including quality-of-life issues as part of new and complex theoretical concepts examine the linkage between different levels and spheres of public planning, private living and people's perceptions. The quality of people's lives is considers in relating to possible life improvements arising out of increased public planning (Massam, 2002). Relevant quality-of-life research thus extends to economic, social, cultural, environmental and other indicators, including the condition of transport infrastructure (Gukalova, 2009). Simultaneously, there has been a paradigm shift in regional planning and transport planning away from planning using volume indicators and towards socially-oriented indicators. This change in thinking is reflected in a shift of focus from transport-service providers to the clients thereof (Bugromenko, 2011).

Furthermore, geography as a discipline operates with a significant set of research approaches and methods by which transport systems may be studied in both the spatial and temporal contexts. While scientists working on the development and determination of transport infrastructure traditionally used area density coefficients and Engel, Goltz and Uspensky coefficients, indexes based around graph theory were introduced later (Pashinska, 2013). Thus a Multimodal Accessibility Indicator can be used as part of a constant monitoring system, or as a tool by which to evaluate the effects of new developments in transport and the attendant infrastructure (Rosik et al., 2017).

Also important is research on transport and sustainability, whose central argument is that public transport is a necessity if a sustainable transport system is to be put in place, with achievement of a version of sustainability that is efficient economically, sound environmentally sound and acceptable socially (Richardson, 1999; Murray, 2001; Banister, 2008; Williams, 2017). This focus 
is important as public resources are borne in mind, given that more people per hour can be carried by public transport than by any other form or means.

Today, over $54 \%$ of our planet's human population is urban, while the figure for Ukraine is actually higher at $60 \%$. In the Ukrainian capital, Kyiv, the need for a sustainable urban transport system has been growing significantly. Overall, transport systems in Ukrainian cities and elsewhere offer citizens from different places (including areas needing to be seen as "remote" for one reason or another) access to places of work and study, and to various services. They also act as a factor affecting the social, economic and environmental aspects of people's lives. The message from real-world examples discussed in many progressive cities and present in the literature cited above is that the effective operation of city transport plays the major role in assuring all groups of a high quality of life.

And so to the main focus of the research detailed here, which is the public transport system in Kyiv, and its influence on city residents. The overall objectives have been to analyse the social and spatial impacts of Kyiv's transport system, by reference to accessibility and quality of life enjoyed by Kyiv's inhabitants, and with a view to a vision by which to improve the existing situation being formulated. The analysis referred to has been based around four interrelated components, i.e. average weekday travel-time accessibility to the centre of Kyiv from certain districts, by means of public transport; average weekday flow of passenger traffic at stations along the routes taken by Kyiv's underground railway and a brief analysis of transport safety, comfort and environmental friendliness as dimensions to sustainability. The fourth component then involves recommendations offered to Kyiv in the hope of its situation vis-à-vis transport being improved.

\section{Theoretical background}

The theoretical starting point regarding the social meaning of the transport good is Walzer's 'Spheres of Justice' (Walzer, 1983). The Walzer approach calls on society to reflect upon the social meaning of goods available within it, on the need for the distribution of particular goods in a separate sphere to be regulated, and on the underlying principles that should guide that process by which the said goods are shared out. When it comes to transport (and its study), Walzer's theory of justice raises three key questions. The first question concerns the social meaning of the good that is transport; and here Martens feels that the overarching transport good can be broken down into the factors of potential mobility and accessibility (Martens, 2009, 2012). The need to distinguish between mobility and potential mobility is stressed, given that the latter often refers to a person's ease of movement through space (with elements of capacity therefore denoted). The term mobility also describes the actual movement of people, with an increase in mobility thus taken to imply travel over longer distances and/or more frequently. In contrast, an increase in potential mobility only implies an increase in a person's capacity to overcome distance, with no suggestion that this capacity is necessarily being made a reality (Martens, 2012).

Accessibility refers to the ease with which destinations can be reached from a given location in space (Farrington \& Farrington, 2005; Dong, Ben-Akiva, Bowman \& Walker, 2006; Niemeier, 1997). Logically, two forms that have come to be distinguished in the literature are person accessibility and place accessibility. Person accessibility is thus an attribute of a person, who either enjoys or does not enjoy possibility or potential to reach a certain set of locations. Place accessibility is in turn an attribute of an activity location, which is accessible or inaccessible for a certain set of people, or from a certain set of other locations. 
The thinking of Geurs and Ritsema van Eck (2001) has accessibility evaluated by reference to four components. While the land-use component reflects the land-use system, the transport component describes the transport system, expressed as the disutility involved as an individual covers the distance between an origin and a destination using a specific mode of transport. The temporal component reflects temporal constraints, i.e. the availability of opportunities at different times of the day, and the time available for individuals to participate in certain activities (e.g. work or recreation). Finally, the individual component reflects the needs, abilities and opportunities of individuals. These characteristics influence a person's level of access to transport modes and opportunities distributed spatially; they may also exert a strong influence on results regarding total aggregate accessibility (Geurs \& Ritsema van Eck, 2001).

By referencing the importance of spatial and temporal properties of people's social networks (work, leisure, friendship and family), Cass, Shove and Urry (2005) identified four key dimensions to access, i.e. the financial, physical, organisational and temporal. According to the authors in question, networks seem central to many aspects of social life, with people having to access networks if they are to participate in a complex, multiply-networked society. Where nodes in such networks are located at a geographical remove from where people live or work, access involves communications and intermittent travel. In the context of social-spatial exclusion these authors defined access as the ability to negotiate space and time so as to accomplish practices and maintain relations that people consider necessary for normal social participation (Cass et al., 2005).

As they focus on public passenger transport, Geurs and van Wee (2004) define accessibility as the extent to which land-use and transport systems enable groups of individuals to reach activities or destinations by means of modes of transport (Geurs \& van Wee, 2004).

In making the connections between transport, accessibility and mobility via the discourse of social inclusion, Kenyon, Lyons and Rafferty (2001) argue that there is a 'mobility dimension to social exclusion'. The process by which people are prevented from participating in the economic, political and social life of the community thanks to reduced accessibility to opportunities, services and social networks are due in whole or in part to insufficient mobility within a society, and also an environment built around the assumption that the level of mobility will be high (Kenyon et al., 2001).

Qualitative and integrated public transport is considered a tool in smart and sustainable mobility, one of whose main goals is to meet the needs and travel demands of the population. A requirement for that is that travel via an accessible and reliable system of public transport should be promoted (Gutierrez et al., 2011). Sustainable mobility is further an alternative paradigm for the strengthening of links between land use and transport in the urban environment; and the application of an approach related to it entails measures aimed at reducing the need for travel (less travel per person), encouraging the use of public transport, walking or cycling i.a. as an option for reducing travel time, and promoting improved transport efficiency systems (Banister, 2008). Smart mobility represents a paradigm shift to a more flexible and multi-modal public-transport system that has no negative effects on the environment and also allows for seamless, efficient and flexible travel across various modes. These are goals necessary if sustainable city development is to be achieved (Hessel, 2015). 


\section{The social meaning of the transport good}

The functional type of development in different quarters of a city depends on spatial patterns. Space by its very nature is divided into centre and periphery, and this pattern does not lose its significance just because a city is involved. As a rule, it is in the centre of a city that all types of activity are concentrated, while peripheral regions serve primarily as some kind of dormitory space. As a result, social dimensions to the transport good are addressed from a starting point in which inequality of accessibility is an inevitability. While transport policies cannot correct the disparity between centre and periphery, they may at best identify and redefine the relationship between them (Martens, 2012).

The process of modern city growth is accompanied by urban sprawl and people's relocation to new suburban areas at just the same time as activities concentrate more and more fully in a city centre. The spatial distance between the residential areas and places of employment and services is thus extended, with this pattern of development increasing time taken to commute, as well as the effort needing to be put in by citizens travelling to work and from work to home, with more residents thus using public transport, and with average numbers of trips taken per capita increasing. All of these movements place greater pressure on the existing transport network, and especially on certain modes of transport. Under those conditions, it is important that methods used relate to the organisation of urban transport systems capable of minimising passenger fatigue while also ensuring that a positive effect on economic and social aspects of people's lives is exerted (Vakulenko \& Dolia, 2015).

Direct and mediated influence of transport on the population is important in large cities. The direct influence arises with improved access to social facilities (like hospitals and educational institutions), as well as places of employment and recreation, this being the result of modernisation of vehicles and infrastructure, with a further aspect being that convenient places for transplanting various users of public transport are foreseen actively.

The mediated influence in turn acts through economic mechanisms, contributing to the overall economic growth of the state and, accordingly, to improved living standards of the population. Thus privatisation and subsequent renovation of the transport infrastructure of a port facility contribute to an improved economic and geographical position for the city, which also sees new jobs created and foreign investment attracted. The next steps would address the needs of the population and their reaction to changes. Together these developments should and would be reflected in improved wellbeing for inhabitants and economic activity.

The mediated negative effects of transport include those on the natural environment and the living environment for a population, the threat of road accidents and technogenic risks, and impacts such as those whereby roads act to separate (eventually even administratively) what had been unified and socially-integrated territories (e.g. local communities).

Problems with transport and the location of services can or may contribute to social exclusion as they prevent people from participating in work or learning, accessing healthcare, or even food shopping and engagement in other local activities. In addition, people in deprived communities even suffer the worst effects of road traffic due to pedestrian accidents, pollution and so on (Social Exclusion Unit, 2003). What is more, the more mobile a society becomes over time, the more certain groups are excluded from that, and/or subject to disproportionate impacts. This reflects increased pressure to use a car, as other transport options increasingly become unavailable in the context of a car-dominant land-use and transport system (Lucas, 2011). 
Transport costs and, in general the overall impact of relatively more-limited transport accessibility places the main burden on the poorest people still lacking a vehicle of their own, who thus have limited mobility and are compelled to use public transport most. The places of residence of the poor are often distant from their possible places of employment and services, given lower housing costs in remote areas, or indeed the availability of free housing offered by local authorities. Ultimately, the poorest often experience transport services of poor quality that denote uncomfortable transfers and long waiting times (Allport, 2000).

The fact of transport costs being high in relation to average personal income limits potential mobility. A person will think through, weigh all the pros and cons, before making or not making a trip, if the cost of relocation affects the family budget negatively. The likelihood of this is especially high if trips to and from a given destination are required daily.

Church, Frost and Sullivan (2000) identified 7 specific features of a transport system that exclude certain groups in the population socially, with these relating to physical exclusion; geographical exclusion; exclusion from facilities; economic exclusion; time-based exclusion; fear-based exclusion and space exclusion. All represent important considerations as the impact of a transport system is being assessed.

The predominance in urban-transport systems of private cars not generally affordable for poor people only serves to further isolate and displace those dependent on public transport. An underdeveloped public-transport network is associated with reduced physical access to places of employment and study, medical-care and cultural facilities, with levels of provisioning in goods and services reduced in consequent, at times even to an extent that threatens food security. Higher costs of transport impact upon standards of living in the population, also restricting participation in public life and even threatening the personal safety of citizens during times of increased movement.

The psychological condition of inhabitants of remote areas also deteriorates with people's awareness of their own 'uselessness' and lack of prospects. A large number of transfers, traffic congestion, obsolete vehicles and unsatisfactory sanitary conditions can also cause psychological overload.

In the case of Ukraine, complaints from those living in large cities relate to the quality of vehicles, the system of transport transfers and the levels of service provided. Another important issue is the condition of roads and pavements, as well as maintenance depots that are characterised by significant levels of wear and tear. Kyiv has to manage without controls on traffic flow, with routes unregulated and non-integrated and with adjacent areas and public spaces transformed into car parks, to the detriment of the environment (e.g. thanks to pollution), and with expecting priority decisions to be taken by municipal authorities.

\section{Approaches and methods}

The spatial mismatch hypothesis presented above assumes greater distances between activity and home location of disfavored groups of population. However, we fully accept that representatives of such groups can also reside in well-served areas, for example, in the inner city. Furthermore, scholars like Scott and Horner (2008) - draw on their empirical findings to make claims that represent a significant departure from other studies in the social-exclusion literature suggesting that the latter is contributed to by poor accessibility. Equally, the empirical studies in question were conducted in North America, where the urban pattern and transport systems are quite different from those in Ukraine. 
For our part, work on urban public transport as a mobility tool encouraged our adherence to the centre-periphery concept, with considerations of transport accessibility in Kyiv resting on the assumption that the city centre is important as a key location for core businesses and related activities and opportunities. Indeed, the significance of central Kyiv has been determined historically, as for centuries this area has played host to cultural, architectural and religious sites, administrative and social institutions and entertainments. This left peripheral neighbourhoods mainly serving dormitory functions. Contrasts central and peripheral areas became even more acute during the Soviet era, when the canons of functionalism were applied in urban planning. Kyiv's problems as regards transport are also intensified by hypertrophied development of the Ukrainian capital, in which the population continues to grow steadily with internal migration. The problem of the centre of Kyiv being overloaded with administrative, business-related and other activities has been contributing to certain creative ways of developing alternative centres in peripheral areas, with the principle of polycentrism therefore being pursued. This thinking has been discussed in various municipal political documents, for example, in the Strategy for the Development of Kyiv through to 2025 (Strategy, 2011).

Our research into the social aspects of Kyiv's transport situation was conducted both in the field and at our desks. Specifically, the work came in two stages, with field observations and a survey of Kyiv dwellers followed by analyses of data collected and of statistical and normative official documents and public reports. The bulk of methods applied relate to visual observations and surveys, specific methods proper to human geography, and statistical, comparative-geographical, systematising, cartographic and historical methods. The isochrones method is used to create a cartographic model displaying average weekday accessibility of Kyiv's centre by public transport.

\section{The social meaning of Kyiv's system of public transport}

\section{General overview}

Kyiv has a transport network that consists of highways, railways, underground, waterways and bridges. The level of saturation of the territory by the road transport network in Kyiv is significantly lower than in most European capitals and major world cities. At present, there are 1,630 km of roads, 150 bridges and overpasses (including 8 bridges across Dnipro), and 221 underground pedestrian crossings in the capital. The length of the street network is $624.8 \mathrm{~km}$.

The system of public transport includes bus, subway (underground), tram and trolleybus services. There is also a funicular railway and a city train. Kyiv's network consists of 107 bus, 45 trolleybus and 21 tram routes, as well as 2 high-speed tram lines. There are 3 underground railway lines: Sviatoshynsko-Brovarska (18 stations along $22.7 \mathrm{~km}$ of line), Obolonsko-Teremkivska ( 21.0 km, 18 stations) and Syretsko-Pecherska (23.8 km long, 16 stations). The Podilsko-Vygurivska and Livoberezhna lines have been the subject of discussion and even planning for many years among those seeking to resolve transport problems in the left-bank part of Kyiv, but these lines are still far from existing. Today's underground-railway network is of 52 stations, with 3 transfer nodes. The total length of track is $69.6 \mathrm{~km}$ (Kyivpastrans 2017). One of the main, if inconvenient and even dangerous means of transport in Kyiv and its suburban areas is marshrutka (a private shuttle-taxi). At present, the city overall is experiencing a trend to be regarded as positive, given a gradual reduction in numbers of routes for private carriers and a gradual expansion of public-transport routes (Dronova \& Boklag, 2017). 


\section{The accessibility of the centre}

In analysing the accessibility of central Kyiv from different districts, via different modes of public transport, we used and constructed isochrones. The result is a map showing public-transport accessibility of the centre as an area in which economic activity, jobs and services all concentrate (Fig. 1). Examination of this map both reveals disproportions in the development of the transport network and suggests ways in which they might be overcome.

The place chosen as the 'city centre' was the starting point for calculations of accessibility. This is in fact Bessarabska Square, which is equidistant from subway transfer stations in the downtown area. The construction of isochrones identified clear and distinct patterns regarding the individual factors that relate to accessibility.

In Kyiv's public transport system, the underground railway represents the most-convenient, reliable and safest mode. It accounts for $38 \%$ of all trips taken when it comes to the modal split of public transport options (World Bank, 2016), and the existence of its many stations constitutes the main factor reducing travel time to the centre. Almost all the long 'tails' of the isochrones are oriented with the metro lines, forming on both sides of the Obolonsko-Teremkivska line and extending widely. There has been a clear raising of accessibility of Bessarabska Square from Teremky district, thanks to the opening of new stations. Similar 'tails' stretch along the SviatoshynskoBrovarska line, though left-bank 30-minute isochrones do not extend to the terminal stations, as these are simply too remote physically (Fig. 1).

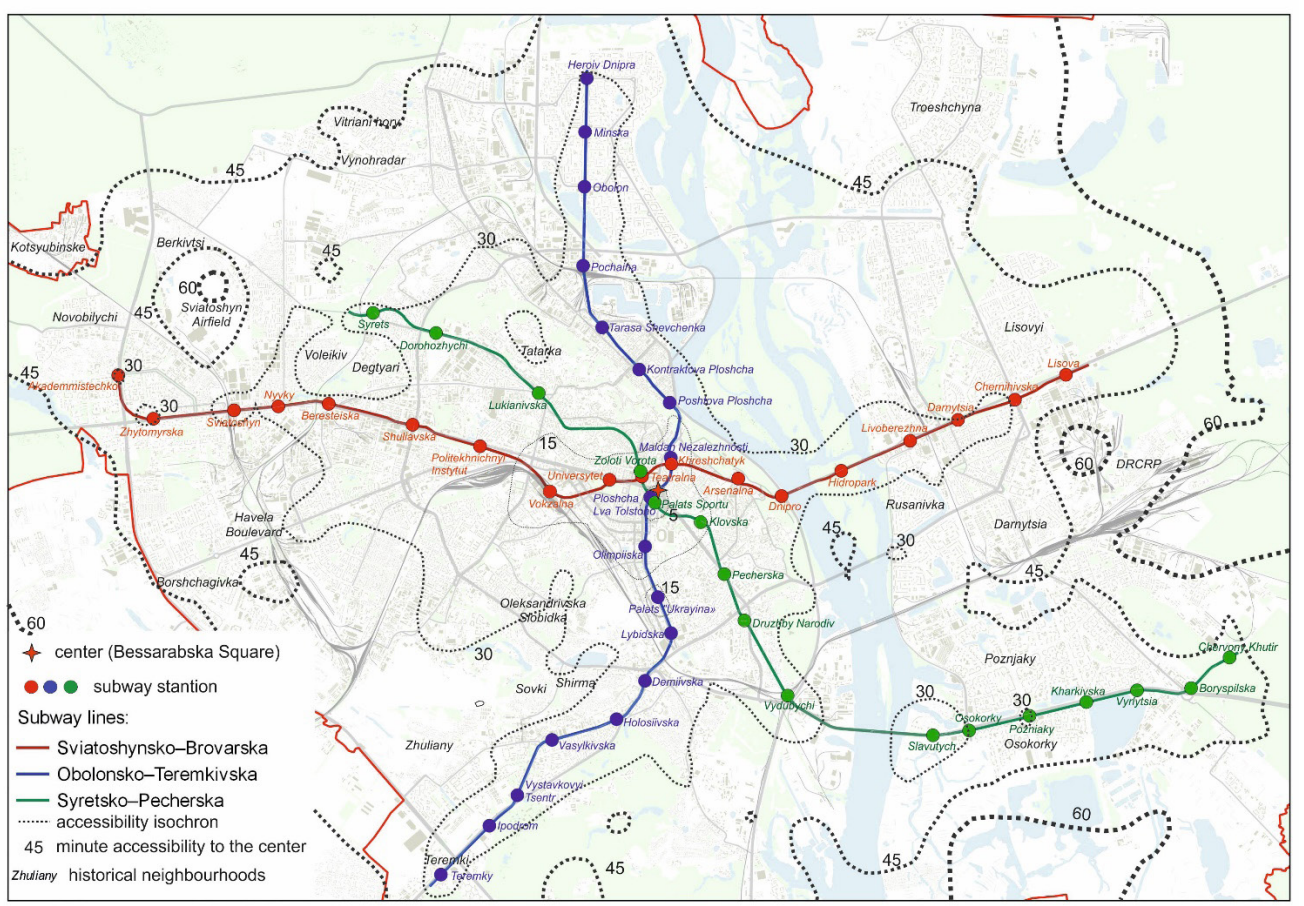

Figure 1. Average weekday accessibility of the centre of Kyiv by public transport, in minutes 
Historical neighbourhoods of low accessibility are identified in Fig. 1. Such a characteristic applies in areas like Troeshchyna, Osokorky, Poznjaky, Kharkivskiy, the Darnytskyi Railway Carriage Repair Plant (DRCRP), Tatarka, Sovki, Shirma and Oleksandrivska Slobidka, and others. Individual factors influencing commute-times in these cases are as described below.

The specifics of Osokorky, Poznjaky and Kharkivskiy neighbourhoods are such that clear concentric and closed isochrones form around the underground-railway stations. A lack of bridges across the Dnipro make movement to the city centre difficult. Low accessibility is connected with both the low level of spatial concentration of streets and locations of neighbourhoods that are distant from main roads and transport connections. If they are to take a trip to the city centre, residents of remote quarters of these districts must devote a large amount of time to even arrive at a metro station. Problems also arise because of the way a railway 'cuts' the left bank, reducing accessibility significantly. Areas adjacent to the railway thus have poor accessibility, despite the relatively short physical distance separating them from the city centre. A particularly difficult situation is to be noted in the area around the DRCRP. This is one of the few densely-populated areas of Kyiv in which closely-packed 60- or even 70-minute isochrones form. In practice, the time required to reach the centre from here is $1.5-2$ hours, notwithstanding the fact that this is a problem resolvable if overpasses over rail lines are built.

Areas not so far from the city-centre physically, but still experiencing limited accessibility include the Tatarka, Sovki, Shirma and Oleksandrivska Slobidka neighbourhoods - given their complex relief, winding streets and one-storey buildings. Degtyari and Voleikiv also fall into the category thanks to the presence of the railway line and the lack of overpasses. A similar situation exists along Vaclav Havel Boulevard, a hard-to-reach area despite its being a centre of business activity.

The most problematic remote neighbourhoods of larger size are Troeshchyna - in its entirety beyond the 40-minute isochrone, Borshchagivka, and Vynohradar, all which are accessible within 40-50 minutes. A high-speed tram line has improved the situation in Troeshchyna somewhat, but the lack of a connection with the right bank reduces greatly the impact of this mode of transport in reducing commuting time.

Kyiv has problems relating its airports. Berkivtsi is cut off from the city by the Svyatoshyn service airfield. Likewise, above and beyond the negative social effects associated with noise and safety, the territorial enclave relating to 'Kyiv' Airport ('Zhuliany') acts to worsen the accessibility of adjacent areas considerably. This factor may be reduced in impact after the planned construction of an underground line from the Ipodrom metro station in this direction and the extension here of the Podilsko-Vygurivska line. In the future, transfers to the airport outside the city should be more effective.

It should also be noted that the main vector of Kyiv's development in recent years (towards the west and southwest) has slowed precisely because proper transport infrastructure is lacking. Most of the areas developed are located outside the 50-minute isochrone.

The aforementioned areas are heavy populated, and accessibility is also affected by the rather high costs of using public transport as compared with the average wage. According to a World Bank household survey, journeys to access employment and education represent $55 \%$ of all the trips taken in Kyiv - even where children and students are excluded. Since July 2018, the price of a oneway ticket on Kyiv municipal transport of any kind has been $8 \mathrm{UAH}$, while the official minimal salary as of December 2018 was of $4173 \mathrm{UAH}$. However, students, who are estimated to represent about $14 \%$ of the city's population (World Bank, 2016) receive a monthly grant of 1100-1600 UAH, meaning that with just one public-transport trip to and from the place of education each day, some $30 \%$ of the support extended will be spent. 
The transport situation of Kyiv's poorest is also worth commenting on, as transport services on a low level have been typical historically given the establishment of remote residential neighbourhoods for the working class in the middle of last century. The current process of inner-city gentrification also furnishes examples of lower-income groups of citizens removing to such remote areas of the city as Osokorky, Poznjaky, Troeshchyna and Vynohradar. At the same time, official data indicate that the largest numbers of employment opportunities are still-more concentrated in the centre than they were (World Bank, 2016). We can thus assume combined influences of factors like low accessibility, insufficient mobility, and relatively high fares contributing to manifestations of geographical and economic exclusion in the city, especially in the cases of those living in remote residential neighbourhoods.

\section{Flows along Kyiv's underground railway lines}

An analysis of average weekday passenger traffic at Kyiv's underground stations confirms the situation with accessibility and also demonstrates a pattern of both centripetal and centrifugal flows. The most-overloaded stations are remote nodes which cumulatively service their own neighbourhoods as well as adjacent ones obviously lacking direct access of their own. Our research reveals that the Sviatoshynsko-Brovarska line is the busiest (Fig. 2). The maximum daily average passenger traffic is that recorded at Lisova Station, with its 58,800 passengers a day. That station services Lisovyi, suburban passenger traffic to Brovary and towards Chernihiv, and part of the passenger flow from Troeshchyna. Livoberezhna and Darnytsia stations also take part of the traffic from Troeshchyna, as well as serving the large residential areas of Rusanivka and Darnytsia. This flow increases the load on this station markedly. Akademmistechko Station on the other side of the line is also much burdened (by 56,600 people a day). When the latter was constructed, it was located at the edge of the city, but now it serves the large residential districts of Novobilychi and Kotsyubinske, with suburban passenger traffic first from the newly-built and densely-populated dormitory suburbs of Sofiyska-Borshchagivka, Irpin and Bucha. Khreshchatyk Station carries significant passenger traffic given its concentration of employment and business venues, related activities and tourism in the city centre. The other heavily-loaded node on the line is Vokzalna Station (54,000 a day served), again thanks to the various traffic flows (including by rail) that concentrate here.

The maximum passenger traffic imposed on the Obolonsko-Teremkivska line is at the Minska and Pochayna stations (respectively dealing with 46,800 and 44,400 people daily). Pochayna is an important transport hub with a major commercial zone including passenger flow from Troeshchyna. This is the Kyiv line developing most dynamically in the $21^{\text {st }}$ century. It is also an area that has participated in a considerable expansion of transport accessibility in the city thanks to links between the centre and Teremky, and a suburban area to the south, as well as areas along the Great Bypass Road. These changes stimulated residential development and business activity in both areas.

The Syretsko-Pecherska line is least loaded, though its peak passenger traffic (noted at Lukianivska Station) is of 40,000 per day. This Station serves a district with business functions and places of employment, and also receives flow from Tatarka. This line was developed actively in the 2000s, but the southeastern direction appears not to have been justified. In fact, development here was slowed by the presence of the forest belt to the east and the industrial zone to the north. As a result, remote stations in the east, viz. Vyrlitsa and Chervonyi Khutir, have only light passenger traffic. While a promising solution to the east may involve a rail connection between the terminal metro stations on the left bank and the town and airport of Boryspil, the projects entailed are ones for the further future. 


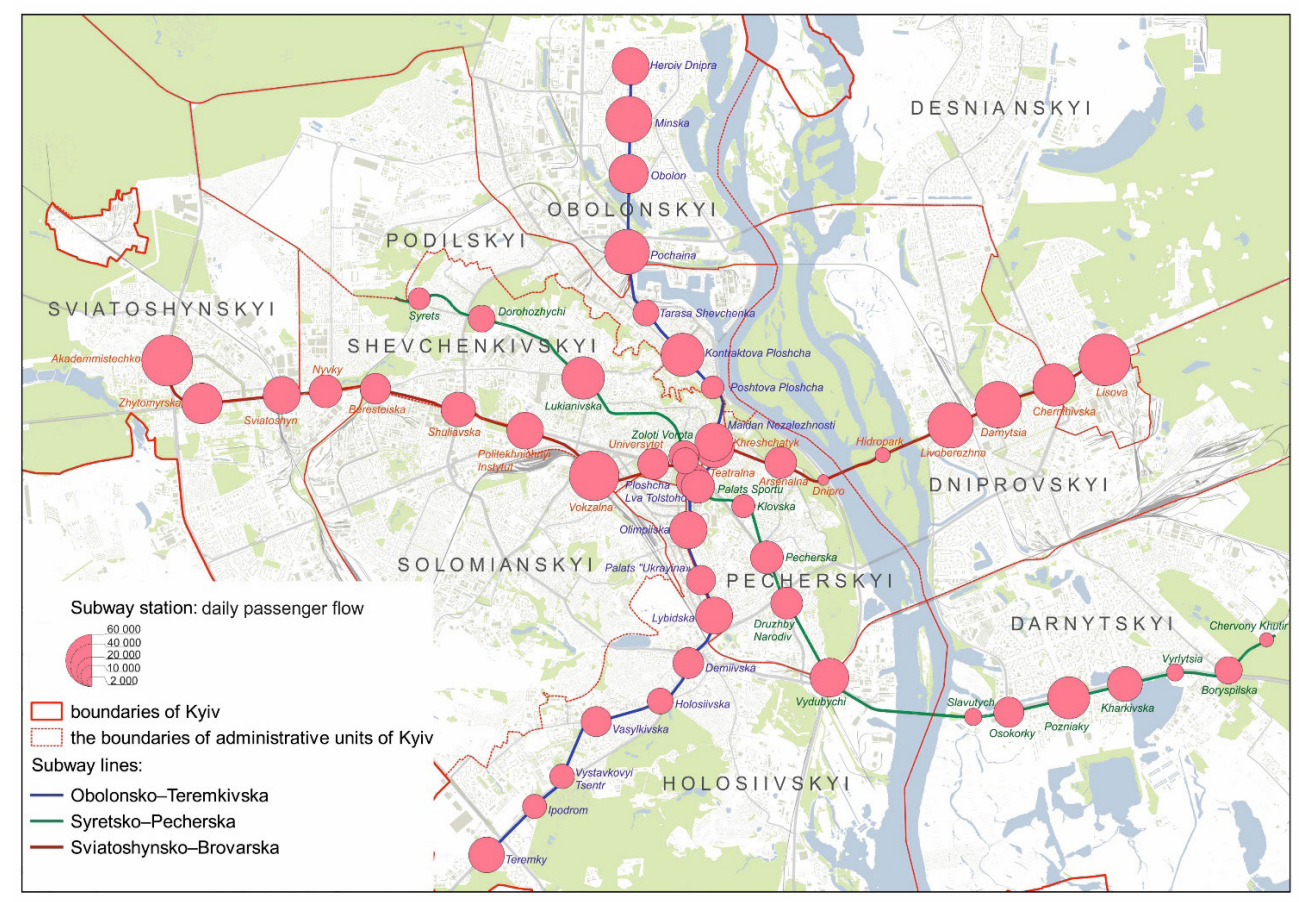

Figure 2. Kyiv's system of underground railways: average weekday passenger traffic flow, 2017

The stations at Posnyaky (serving 38,800 a day) and Kharkivska (26,800 thousand) collect flows from adjacent neighborhoods. Vydubychi Station, regarded as a key node of growth, combines a rail connection and bus services (including intercity and international), and has a multi-level car interchange and a network of tunnels and transit areas connecting all modes of transport.

The most overloaded stations are thus Lisova, Minska, Pochayna and Akademmistechko located in remote districts, as well as the transfer nodes of Vokzalna and Lukianivska in the central part of the city.

\section{The sustainability of Kyiv's public transport}

Accessibility, safety, reliability, convenience, informativeness, environmental friendliness and comfort of transport are what largely determines the overall assessment of the city's sustainability, with respect to smart mobility in particular. The transport system of the capital of Ukraine is only beginning to adapt to the needs of people with disabilities. The level of transport expenditure affects the welfare and mobility of the population and the number of accidents, the degree to which rolling stock is wearing out and the qualifications and responsibility of drivers. All are important indicators related to living and living safely in the city. Emissions and noise related to transport represent additional, important indicators where the impact of the system on the environment and on human health is concerned.

At 8-10 years, the age of transport rolling stock in Kyiv is considerably lower than in other Ukrainian cities. This denotes a relatively high level of comfort and innovation of transport, albeit still on far lower levels than in other European capitals. Most Kyiv buses and trolleybuses are low- 
floor buses - a matter of considerable importance to pensioners, children and those with disabilities. The use of new low-floor Electron T5B64 trams with their air conditioning, heating, video surveillance, mobile charging points and Wi-Fi looks very promising.

Reforms seeking to improve the city's transport system are underway, as are plans for all transport and transfer stops to be equipped with new navigation systems. Electronic signs with route and transfer schemes are to be fitted in rolling stock. A revolutionary breakthrough in the field of information support of urban transport is an open online EasyWay service (www.eway.in.ua) that allows optimal routes for public transport to be sought, costs of travel calculated, and information on the schedule and equipment of transport infrastructure for people with disabilities obtained.

On the other hand, problems remain with the number of transport units along routes, unsuitable interchange nodes, long waiting times, and inconsistencies at transit stations. In addition, the city has yet to introduce travel via a single integrated e-ticket for all types of public transport.

The issue of transport safety is much-discussed in Kyiv. The safest modes of transport are funicular railway, tram and underground railway. The most accident-prone form of travel is in turn the marshrutka (fixed-route taxi). Official data available on this show that most road accidents with serious consequences are due to:

- speeding by drivers (as the main cause of death in 39\% of cases);

- undeveloped (under-lit, improperly-marked) pedestrian crossings (the cause in $38 \%$ of cases with fatal consequences);

- violation of rules on crossing at intersections (accounting for up to $30 \%$ of all traffic accidents resulting in death);

- driving vehicles while in a state of alcoholic intoxication (Strategia, 2017).

According to the regional report on the condition of the environment in Kyiv in 2015 (MENR, 2015), the overall level of air pollution in the city is above the average for Ukraine and assessed as 'high' by experts. The main polluter of air in the city is auto transport (accounting for $84.4 \%$ of all harmful emissions to the atmosphere). Bessarabska and Demiivska Squares are the places noting highest air-pollution levels, due to their lower relief and the presence of intensive traffic on nearby main roads.

The excessive level of car use in Kyiv can be considered evidence of the imperfections and inconvenience of the public-transport system. On the other hand, motor vehicles are a factor displacing public transport from the urban transport system and standing in the way of its development. The number of cars per 1000 people in Kyiv currently is 353 (the average for Ukraine is 202, but was just 84 as recently as in 1996). The city is characterised as having a growing 'transport fatigue' factor. Car transport is the source of $80-90 \%$ of all external noise in the city. Further separate but significant problems relate to the lack of parking spaces, and to conflicts between cars and pedestrians and in respect of green zones.

\section{Discussion on prospects for an improved transport situation in Kyiv}

The trend towards increased motorisation, the frequent accumulation of vehicles on roads crowding out public transport, and the ageing of public-transport infrastructure and rolling stock are all typical for Kyiv. Comparisons between moving people in private vehicles and moving them via public transport always show public transport to be both more 'friendly' socially and environmen- 
tally, and cost-effective for communities. However, the balancing act between simply providing an opportunity to use public transport and providing a system that is well-patronised and favoured above other means of transport thanks to quality of provision is critically important. A system of public transport should not be seen as a 'second-choice' mode, but rather viewed by all members of the community (rich and poor alike) as a highly desirable transport choice (Abley \& Williams, 2008). But for public transport in Kyiv to be seen by inhabitants in this way, the transport system will need to pass through a number of dramatic changes.

The primary task if transport accessibility in the city is to be improved is to resolve problems relating to congestion on bridges across the Dnipro. In particular, this goal involves completing work on the Podilsky Bridge crossing and on driveways of the left-bank part of the Darnytsky Bridge (for trains and cars). Bridges north and south of existing ones are also needed, as is the completion of an automobile bridge with transport entrances near the railway bridge. Tunnels can represent an alternative to bridges, though - while plans for them exist - their implementation is more complicated.

Another task would entail accessibility being assured in areas cut off by railways, via efforts to expand the existing network of overpasses, tunnels and so on. In particular, an overpass over lines representing an extension of Suzdalska Street to Volynska Street would be built. This project in fact enjoys the highest priority in official urban-planning documents (Generalniy plan, 2011).

The completion of work on the Great Bypass Road in the northeast and left-bank area will permit transit transport to impacted service areas outside the city. This will increase the accessibility of certain areas considerably, and take part of the load off the street network. It is also necessary for automobile hubs near transfer nodes to be planned, so that transfer to urban public transport is made smoother. Environmentally friendly and high-speed transport (subway, high-speed tram) systems in the direction of remote areas need to be launched. A feasibility study for the launch of a Bus Rapid Transit and tram-train system is also important, and high-priority status also attaches to the extension of the underground railway to Troeshchyna district, or the extension of the highspeed tram running in left-bank areas to the right bank. The main strategic project for the development of the underground involves the Podilsko-Vygurivska line, which is to connect Troeshchyna with the city center, and subsequently be prolonged in a south-westerly direction to Zhulyany and Borshchagivka (Generalniy plan, 2011). Both cases involve reconstruction of the Petrivsky Bridge.

The transition of a one-way traffic system in the city centre has proven successful, and there is a need to expand the network into further such streets. This will allow planners to allocate separate lanes for above-ground public transport, in consequence increasing mobility and passenger turnover considerably. The development of an automated road-traffic management system will also reduce the current number of traffic jams on Kyiv streets.

One of the most radical and effective ways of addressing the city's excessive motorisation may entail the pursuit of measures aiming to limit the use of cars altogether through adequate development of the public passenger-transport system. Different cities have taken a variety of measures and solutions to this end, with some setting fees for private cars to enter a city centre and others banning cars via some administrative policy. A common practice sees use of bicycles favoured, as these are the cheapest, fastest and healthiest means of transport in a city and also reduce carbon emissions to the atmosphere. Nor should the ideas of creating pedestrian zones and pavements for pedestrians be ignored, along with conditions under which people with disabilities can become mobile, as work to design and reconstruction the city's street and road network get underway. Approaches of new urbanism for cities on different levels suggest schemes by which to transit from the 'city for cars' to the 'city for people', and give consideration to changed land-use practices by 
which residential and employment functions are discharged in the same areas, within walking distance of each other. Under the draft plan for sustainable mobility in Kyiv through to 2030, the main priority for the city's transport policy should be people with disabilities, then pedestrians, followed by bicycles and public transport. Those with private cars are in last place.

\section{Conclusion}

Transport rightfully deserves the separate-sphere status it enjoys in Ukrainian society and culture. However, the organisation and functioning of the public transport system in the capital Kyiv reflects a lack of attention to the social meaning of the good that is transport, and the way that good is distributed. The current conditions of public-transport development and the organisational level achieved by transport services in Kyiv do much to pose an obstacle to people, rather than offering benefits. Accessibility analysis and research on the flow and volume of passenger traffic on the underground lines and on sustainability only serve to demonstrate that the transport system in the capital is undeveloped, overloaded and only beginning to adapt to the needs of those with disabilities. Many separate historical neighbourhoods in Kyiv continue to demonstrate low accessibility values for public transport to the city centre, in which all activities remain concentrated. In this context, the circumstances of specific areas have been investigated here, and examples discussed. The results illustrate the problem of social exclusion in the city, though not of course in exhaustive detail; hence the need for further research of a more detailed nature.

The domination of private motor vehicles ensures that the latter are the main source of environmental pollution in the city. The priorities to improve Kyiv's transport system should address the establishment of connections with remote suburban areas, as well as areas on the left bank of the Dnipro in general. Optimisation of public-transport rolling stock and fleets is also a key issue, with gradual withdrawal of the marshrutka form of transport needing to be envisaged. This is another issue requiring more-detailed investigation. The strategic planning objective in the sphere of transport in Kyiv should reduce dependence on private vehicles and increase reliance on public transport. Changes and modifications in public transport are of critical importance. Quality work and a positive image for public transport are needed to encourage its use by the population. Reduced use of cars will also limit environmental burdening on the urban area and population markedly. More widely, environmentally-sound forms of transport play a special role in the achievement of sustainability. Plans to strengthen the links between land use and transport in Kyiv will provide measures aimed at reducing the need for travel, and the volume and duration of travel. Such measures can also facilitate improvements in the quality of human life and reduce the environmental impacts associated with the current system of transport in Ukraine's capital.

\section{References}

Abley, S., Williams, R. (2008). Public transport accessibility levels. In Proceedings of the IPENZ Transportation Group Conference (pp. 2-5).

Allport, R. (2000). A review of transport and the urban poor. World Bank: Washington, D.C.

Banister, D. (2008). The sustainable mobility paradigm. Transport policy, 15(2), 73-80, https://doi. org/10.1016/j.tranpol.2007.10.005

Bugromenko, V. (2011). Modern transportation geography and transportation accessibility. Regional Research of Russia, 1(1), 27-34, https://doi.org/10.1134/S2079970511010047

Cass, N., Shove, E., \& Urry, J. (2005). Social exclusion, mobility and access. The Sociological Review, 53(3), 539-555, https://doi.org/10.1111/j.1467-954X.2005.00565.x 
Church, A., Frost, M., \& Sullivan, K. (2000). Transport and Social Exclusion in London. Transport Policy, 7, 195-205, https://doi.org/10.1016/S0967-070X(00)00024-X

Dong, X., Ben-Akiva, M.E., Bowman, J.L., \& Walker, J.L. (2006). Moving from trip-based to activity-based measures of accessibility. Transportation Research Part A, 40, 163-180, https://doi.org/10.1016/j. tra.2005.05.002

Dronova, E., \& Boklag, E. (2017). Vplyv transportnoi systemy Kyeva na zhyttia ta mobilnist yogo zhyteliv [The impact of the Kyiv transport system on citizens life and mobility]. Visnyk Kyivskogo natsionalnogo universytetu, Geografiya [Bulletin of Taras Shevchenko National University of Kyiv, Geography], 1-2(66-67), 94-100.

Farrington, J. (2007). The new narrative of accessibility: its potential contribution to discourses in (transport) geography. Journal of Transport Geography, 15(5), 319-330, https://doi.org/10.1016/j. jtrangeo.2006.11.007

Farrington, J., \& Farrington, C. (2005). Rural accessibility, social inclusion and social justice: towards conceptualisation. Journal of Transport Geography. 13(1), 1-12, https://doi.org/10.1016/j. jtrangeo.2004.10.002

Garb, Y., \& Levine, J. (2002). Congestion pricing's conditional promise: promotion of accessibility or mobility? Transport Policy, 9(3), 179-188, https://doi.org/10.1016/S0967-070X(02)00007-0

Generalniy plan (2011) Generalniy plan rozvytku m. Kyeva ta yogo prymiskoi zony do 2025 [General plan for the development of Kyiv and its suburbs until 2025]. Retrieved from http://kga.gov.ua/generalnij-plan/genplan2025

Geurs, K. T., \& van Wee, B. (2004). Accessibility evaluation of land-use and transport strategies: review and research directions. Journal of Transport Geography, 12(2), 127-140, https://doi.org/10.1016/j. jtrangeo.2003.10.005

Geurs, K.T., \& Ritsema van Eck J.R., (2001). Accessibility Measures: Review and Applications. Evaluation of accessibility impacts of land-use transportation scenarios, and related social and economic impact. RIVM report 408505 006, Bilthoven: National Institute of Public Health and the Environment.

Gukalova, I. (2009). Yakist zhyttja naselennja Ukrainy: suspilno-geographichna conceptualizatsia: monographia [Quality of life of the population of Ukraine: sociogeographical conceptualization: monograph]. Institute of Geography of NAS of Ukraine. K.: Drukarnja MVS Ukrainy.

Gutiérrez, J., Cardozo, D., \& García-Palomares, J. (2011). Transit ridership forecasting at station level: an approach based on distance-decay weighted regression. Journal of Transport Geography, 19(6), 1081-1092, https://doi.org/10.1016/j.jtrangeo.2011.05.004

Hall, D. (2010). Transport geography and new European realities: a critique. Journal of Transport Geography, 18(1), 1-13, https://doi.org/10.1016/j.jtrangeo.2009.07.002

Hessel, V. (2015). Smart Mobility - A tool to achieve sustainable cities. München: Siemens AG.

Hine, J.P., \& Mitchell, F. (2001). Better for everyone? Travel experiences and transport exclusion. Urban Studies, 38(2), 319-332, https://doi.org/10.1080/00420980020018619

Jaroš, V. (2017). Social and transport exclusion. Geographia Polonica, 90(3), 247-263, https://doi. org//10.7163/GPol.0099

Kenyon, S. (2011). Transport and social exclusion: Access to higher education in the UK policy context. Journal of Transport Geography, 19(4), 763-771, https://doi.org/10.1016/S0966-6923(02)00012-1

Kenyon, S., Lyons, G., \& Rafferty, J. (2002). Transport and social exclusion: investigating the possibility of promoting inclusion through virtual mobility. Journal of Transport Geography, 10(3), 207-219.

Kyivpastrans Communal Enterprize (2017, October 25). Retrieved from http://kpt.Kyiv.ua/information/ about-kyivpastrans/company-history/

Lucas, K. (2010). The role of transport in the social exclusion of low income populations in South Africa: a scoping study. In Proceeding of Transportation Research Board Annual Meeting 10-15 January. Washington DC.

Lucas, K. (2011). Transport and Social Exclusion: Where Are We Now?' In M., Grieco, \& J., Urry (Ed.). Mobilities: new perspectives on transport and society (pp 223-244). Surrey, UK: Ashgate Publishing Limited.

Mackett, R., \& Thoreau, R. (2015). Transport, social exclusion and health. Journal of Transport and Health, 2(4), 610-617, https://doi.org/10.1016/j.jth.2015.07.006 
Martens, K. (2009). Justice in Transport: applying Walzer's 'Spheres of Justice' to the transport sector . 88th annual meeting of the Transportation Research Board, 11-15.

Martens, K. (2012).Justice in transport as justice in accessibility: applying Walzer's 'Spheres of Justice' to the transport sector. Transportation, 39(6), 1035-1053, https://doi.org/10.1007/s11116-012-9388-7

Massam, B. (2002). Quality of Life: public planning and private living. Progress in Planning, 58(3), 142-227, https://doi.org/10.1016/\$0305-9006(02)00023-5

Murray, A.T. (2001). Strategic analysis of public transport coverage. Socio-Economic Planning Sciences, 35(3), 175-188, https://doi.org/10.1016/S0038-0121(01)00004-0

Niemeier, D.A. (1997). Accessibility: an evaluation using consumer welfare. Transportation, 24, 377-396, https://doi.org/10.1023/A:1004914803019

Pashynska, N. (2013). Transformation of Transport Accessibility in Ukraine: Spatial Analysis. Kyivskiy geographichnyi schorichnyk. K., 8, 224-229.

Raje, F. (2003). Impacts of road user charging / workplace parking levy on social inclusion / exclusion: gender, ethnicity and lifecycle issues. Final report. Commissioned from TSU by the Department fr Transport, Oxford.

MENR (2015). Regionalna dopovid pro stan navkolishnogo prirodnogo sredovischa v m. Kyevi za $2015 \mathrm{r}$. [Regional report on the environment state in Kyiv in 2015]. Retrieved from http://www.menr.gov.ua/ docs/activity-dopovidi/regionalni/rehionalni-dopovidi-u-2015-rotsi/Kyiv_2015.pdf

Richardson, B. (1999). Towards a Policy on a Sustainable Transportation System, Transportation Research Record, 1670, 27-34, https://doi.org/10.3141/1670-05

Rose, E., Witten, K., \& McCreanor, T. (2009). Transport related social exclusion in New Zealand: evidence and challenges. Kōtuitui: New Zealand Journal of Social Sciences Online, 4(3), 191-203, https://doi. org/10.1080/1177083X.2009.9522454

Rosik, P., Komornicki, T., Stępniak, M., Śleszyński, P., Goliszek, S., Pomianowski, W., \& Kowalczyk, K. (2017). Evaluation of accessibility changes in Poland using the MAI indicator. Geographia Polonica, 90(3), 361-368.

Ross, W. (2000). Mobility and accessibility: the yin and yang of planning. World Transport Policy \& Practice, 6(2), 13-19.

Scott, D., \& Horner, M. (2008). The role of urban form in shaping access to opportunities: an exploratory spatial data analysis. Journal of Transport and Land Use, 12, 89-119.

Social Exclusion Unit (2003). Making the Connections: Final report on transport and social exclusion, London: Office of the Deputy Prime Minister.

Stępniak M., Rosik P., Komornicki T., 2013. Accessibility patterns: Poland case study. Europa XXI, vol. 24, Warsaw: Institute of Geography and Spatial Organization PAS, pp. 77-93.

Strategia (2017). Strategia pidvyschennja rivnja bezpeky dorozhniogo ruhu v Ukraini na period do 2020. 2017. [Strategy for increasing the level of road safety in Ukraine up to 2020]. Rozporyadzhennya KMU vid 14 June 2017. N 481-p Kyiv. Retrieved from http://zakon3.rada.gov.ua/laws/show/4812017-\%D1\%80\#n8

Strategy (2011). Strategy of Kyiv City Development until 2025. Retrieved from https://kyivcity.gov.ua/ files/2016/11/9/Kyiv-City-Strategy-2025-Project.pdf

World Bank (2016). Sustainable Urban Transport for Kyiv: Towards a Sustainable and Competitive City Built Upon the Legacy System and Innovations. World Bank Report.

Vakulenko, K., \& Dolia, K. (2015). Upravlinnya mis'kym pasazhyrskym transportom: navch. posibnyk [Management of urban public transport: manual]. Nat. Univ. Mis'kogo Gospodarstva im. O. M. Beketova. Kharkiv: HNUMG im. Beketova.

Vigar, G. (1999). Transport for people: accessibility, mobility and equity in transport planning. In C. H., Greed (Ed.). Social town planning (pp. 90-101). London: Routledge.

Walzer, M. (1983). Spheres of justice: a defense of pluralism and equality. Basic Books.

Williams, K. (Ed.). (2017). Spatial planning, urban form and sustainable transport. London: Routledge. 